\title{
Innovation and Diffusion - Different Roles in Developing Nature-Based Tourism
}

\author{
Gunn-Turid Kvam* and Egil Petter Stræte
}

Centre for Rural Research, Norwegian University of Science and Technology, 7491 Trondheim, Norway

\begin{abstract}
Tourism is a labour-intensive industry with the potential to contribute towards the creation of jobs and economic development in many rural areas. Innovation may be a driver of growth in tourism as well. However, there is a lack of empirical knowledge about innovation as a driver of growth in tourism, and its implications for a specific branch of tourism. The present study explores innovation and its characteristics in nature based tourism and the roles various actors can play in innovation processes. The empirical basis of the paper is a case study of sea-fishing tourism in Norway. The case includes a study of 12 suppliers of sea-fishing and accommodation, and a tour operator for such firms. The empirical findings show that product innovations were incremental, and cooperation between firms and a mediator was crucial in overcoming the step from innovation to diffusion. It is argued that innovation can be a crucial driver for establishing and renewing nature-based tourism firms. However, to give significant contribution to business activity and value added, diffusion of innovation is an important activity.
\end{abstract}

Keywords: Nature-based tourism, innovation, diffusion, network, rural development.

\section{INTRODUCTION}

There seems to be consensus on the importance of innovation to assure growth and sustainable wealth for many industries. Innovation is also seen as a driver of growth in tourism [1-5]. Tourism is a labour-intensive industry that has the potential to contribute toward the creation of jobs and economic development in rural areas; it is often seen as the linchpin in many rural development strategies $[6,7]$.

In the growing Norwegian tourism industry, it is primarily the unique natural environment that attracts tourists. As in other countries, we also experience an increased demand for adventure products. This demand has been followed up by authorities, who emphasise the development of adventures - particularly those connected to nature- and ruralbased tourism. Since the late 1990s, several governmental strategy documents have been developed about tourism. For example, a governmental national tourism strategy was published in 2007 [8]. The main goals for the tourism industry include increased value adding and productivity, a more robust industry contributing to rural development and a sustainable tourism industry. Innovation is one of the cornerstones in the strategy to reach these goals.

However, there is lack of knowledge concerning the role innovation plays in the development and expansion of nature-based tourism. One important reason for this knowledge gap is a general lack of research on nature-based tourism and innovation in small rural communities. The present study addresses this gap by examining how innovation, and not least diffusion of innovation, may influence the development and expansion of nature-based tourism in a

*Address correspondence to this author at the Centre for Rural Research, Norwegian University of Science and Technology, 7491 Trondheim, Norway; Tel: +4773591730; Fax: +4773591275;

E-mails: gunn.turid.kvam@bygdeforskning.no; gtk@rural.no county in northern Norway. Specifically it addresses the questions: What kinds of innovations are possible to identify in sea-fishing tourism in the county of Troms, and what characterizes these innovations? What role does a touroperator and other actors in the network of tourism firms' play in innovation processes?

To explore and answer these research questions we first discuss theoretical aspects and previous research on innovation.

\section{PERSPECTIVES ON INNOVATION AND TOURISM}

Many authors stress the differences in producing and marketing tourism products compared to industrial products. According to Weiermair [9] the differences are that: tourism produces and sells product bundles (or experiences) which are very intangible; its products cannot be stored (simultaneous production and consumption); consumption involves the active participation of the customer; tourism production/ marketing may often involve major capital assets; the intermediation, distribution and final consumption stage may often require interaction of different personnel categories (e.g. travel agencies, restaurants, coaches, etc.). These differences suggest the need to look closer at how they may influence innovation in tourism.

\section{What is Innovation in Tourism?}

Until recently, research on innovation in service in general and tourism in particular was absent $[10,11]$. Innovation in tourism is a growing research field, but research is still sparse and fragmented [12, 13]. The term "innovation", which derives from the Latin "innovatio", means to create something new. In literature on innovation in tourism, most authors are inspired by Schumpeter [14]. Based on Schumpeter but adjusted to the service sector, Hjalager [3] propose the following typologies of innovation: 
- $\quad$ Product innovation consists of change or entirely new services or products which are developed to the stage of commercialisation, and whose novelty should be evident to either producers, consumers, suppliers or competitors;

- Process innovation includes renewals of the prescriptive procedures for producing and delivering the services which raise the performance of existing operations;

- Management innovation consists of new job profiles, collaborative structures, authority systems, etc.;

- Logistics innovations include a recomposition of external commercial liaisons;

- Institutional innovations go beyond the individual enterprise, representing collaborative and regulatory structures in small or larger communities.

Schumpeter [15] clearly distinguishes innovation from minor changes. He also stresses that innovation does not equate to invention. This is in line with Kanter's [16] broad definition of innovation where he refers to processes of bringing any new, problem solving idea into use. Acceptance and implementation are central in this definition, thus it involves the capacity to change and adapt. According to Hesklett [17] innovations do not necessarily need to be successful. To be successful, innovations must increase value either by improving quality or by lowering the price (cost).

Innovation can take many forms and can be classified in very different ways. The diversity of definitions lies in the different purposes for examining this phenomenon [18]. Novelty or newness is one of the notions where there have been several competing interpretations [13]. In technological innovation, a product or a process is called an innovation when it is new in the market. Afterwards, there might be improvements that also qualify for being an innovation. If other actors develop nearly the same product or process in the same context it is usually called an imitation [19]. If this way of definition is transferred to tourism firms offering nature-based products, many firms imitate or adapt products. If these firms further improve components from others, they are involved in what Hall and Williams [13] identify as creative imitations. In a narrow and classical sense these products would not classify as innovations. As discussed in Fagerberg [20], however, introducing the same innovation in a new context may imply considerable adaptations and perhaps also incremental innovation. The same may be the situation when innovations are imitated in the same context, since this will also usually demand adaptation to the firm's organisation, technology and context [19]. In a broad sense of innovation and in recent literature in tourism, these phenomena are often considered as innovations [21, 22]. This is in line with Rogers [23] in that, "If an idea seems new to the individual, it is an innovation" (p. 12).

The degree of change is also relevant to innovation. Shumpeter's [15] definition emphasises that innovations are distinguished from minor changes, but when is a change minor? What if a minor change of a product has a tremendous influence on sales, for example a minor change in design of the package of the product? In tourism research, innovation is sometimes broadly defined also in this manner, where minor adaptations of existing products and services are included in the innovation concept as incremental innovations [3, 24]. Results from innovation research in general and in tourism in particular shows that; when innovations occur they are mainly incremental [11, 25]. When we know that an innovation in many cases consists of many small steps of actions that in retrospect may be considered an innovation, it will in many cases be the sum of minor changes that constitute an innovation [26].

Many innovations are developed to be "sold" or transferred to many actors. This process is called diffusion of innovations [23]. Diffusion is defined as "the process in which an innovation is communicated through certain channels over time among the members of a social system" [23] (p.5). When we talk about diffusion of innovations, the innovation is already developed. The concept of diffusion seems not to be commonly used in the tourism literature on innovation, but more in literature on manufacturing industries, where more tangible products are produced. However, in our case we find this concept useful also in tourism, to describe a specific transfer of knowledge from a tour operator to tourism firms. Innovation and diffusion are paired concepts working together. However, the precise divide between the phenomena may be challenging to identify in practice.

The discussion above reveals that it is not always obvious when we can define an activity or a change to be considered as an innovation. In this paper, we base our understanding of innovation in tourism as mainly: new or improved products offered; new or improved processes; new organizational and management models within firms, or involving other organizations or institutions; or market innovation, i.e. new behaviour in the market. Based on such an understanding, an innovation will have come into being by combining resources in new ways and this new combination is implemented into use.

\section{Conditions for Innovation}

Results from previous studies show that the tourism industry is low on innovations and that tourism businesses are mainly imitators and adaptors rather than innovators [3,11,27-29]. Hjalager [3] argues that a number of preconditions that facilitate innovations are not present in the tourism industry. Most enterprises are small scale companies or micro firms, owned by single persons or families. The capacity for innovation seems to be closely and positively correlated to the size of enterprises [23, 30]. Small firms often lack the capacity and competence to search for and utilize information and knowledge [31]. Entrepreneurs in tourism often have an irrelevant background and are attracted by the idea of pursuing a certain lifestyle rather than adhering to traditional career issues of prestige, money and progress [32]. Little cooperation is found among tourism firms, and there is little mutual trust among tourism enterprises. Tourism actors see each other more as competitors than as co-operative partners. To collaborate, tourism firms often need intermediation by other organizations, where activities are undertaken at "armslength" from the individual firm [3]. Managers and staff usually have low levels of education and training in the 
industry. Labour turnover in tourism exceeds the turnover in most other sectors of the economy and a large number of persons are usually engaged on short-term contracts. The fact that the sector pays low salaries and has non-standard working conditions makes work in a tourism firm less attractive for a lot of people [33]. A number of preconditions that facilitate innovation are thus not present in the tourism industry. Despite these findings, other studies have found parts of the tourism industry to be rather innovative. For example, Jenssen et al. [25] found that attraction firms, travel agencies and transport enterprises were innovative. This is confirmed by two Norwegian studies that show relatively high activity of innovation in small-scale rural tourism [22] and nature-based tourism [21]. Another main point in research is that innovations seem to occur in related industries closely connected to tourism firms, such as transport, by operators, etc. $[13,25]$. These firms may be called drivers or pushers of innovation in the tourism industry.

Knowledge is one crucial resource for a firm's ability to be innovative, and the ability to acquire new, relevant knowledge. According to Valentine [34] innovations may be a result of interplay between the existing knowledge base and routines for generating new knowledge. To be able to generate new knowledge, Valentine claims that actors need "inducement capacities", i.e. the ability to observe problems or possibilities. Second, actors need the capacity to seek and assess possible solutions for their potential and relevance, and third, actors need the capacity to design possible solutions and transform these to usable solutions. Innovations may be based on different kind of knowledge. One distinction is made between codified and tacit knowledge. Codified knowledge is knowledge that can be made explicit, and therefore can be transmitted in formal and systematic ways. In contrast, tacit knowledge is personal and context-specific and mainly based on experience. Polanyi [35] characterizes tacitness as the elements of knowledge and insight embodied in each individual which are poorly defined, not codified or published and therefore cannot be expressed. Polanyi's definition has since been refined, such that tacit knowledge is not limited to individual knowledge. The tacit dimension of interacting in networks and clusters is seen to be one of the more promising competitive advantages in future tourism. Tacit interaction depends on complex mixtures of judgement, problem solving and information exchanges, often involving group behaviour that is difficult to replicate [13].

Firms can acquire knowledge both internally and externally. In tourism, the front stage processes are highly visible and the level of technology relatively unsophisticated [13]. Therefore it may be relatively easy for competitors to imitate products offered from others. However, as many of these service quality innovations are dependent on tacit knowledge, there are constraints on learning and imitation through observation [13]. On the other hand, Keller [36] claims that imitations are one of the most important means of disseminating innovations in the field of tourism. Inter-firm exchanges, which usually means collaboration with other tourism firms or suppliers, is also an important source for knowledge, and geographical clustering may facilitate the development of strong levels of trust and shared values which leads to high levels of mutually beneficial knowledge exchange. Another channel for knowledge is "knowledge brokers" [13]. These are influential individuals who operate within and across company boundaries, and act as bridges for knowledge transfers between different communities. Consultants constitute one example of the highly institutionalized broker, and as we will see in our presentation of results, a tour operator may also take such a role. Last but not least, customers are also one of the most important actors influencing innovation in tourism firms [13]. A Norwegian study of nature-based tourism revealed that interaction with customers, competitors, neighbours, the local community and a regional interest organization was of importance for gaining ideas and knowledge in innovation processes [21]. In another study of innovation in Norwegian small-scale tourism firms, results show that "cooperation, market information system and actions to increase the firms' knowledge and competence seemed to be particularly important to increase the firms' innovative capacity" [22] (p.16).

Innovation is seen to be a relational activity which has to be understood as being situated in particular institutional contexts. Fisher [37] uses the notion of "systems of innovation" to describe this. From evolutionary theories of innovation, an influential perspective on innovation systems is developed [38-40]. Theories and empirical research on innovation systems focus on which elements are important, such as production structure, clusters, R\&D, education, internal organisation, inter-firm relations, the financial system, and networks in general. The innovation system approach is also applied on a regional level, in regional innovation systems (RIS). Where innovative organisations at a regional level are set in an institutional milieu "where systemic linkage and interactive communication among the innovation actors is normal", they may constitute a regional innovation system [39]. A Danish innovation study of tourism showed that classical innovation systems as such could not be identified, but individual networks and external and internal organising for innovation were found to be very important for the development of specific tourist products [25]. Participation in several specific networks was also found to be important. In this paper we explore these issues further.

\section{METHOD}

Earlier studies in the field of tourism and innovation have often been hypothetical-deductive approaches employing structured instruments on large populations e.g. [24]. However, to address the research questions of the current study, to study innovation in small rural nature based firms in a region, and to search for drivers of innovation, we chose a qualitative approach. In qualitative approaches, phenomena such as innovation are perceived as complex and embedded within dynamic processes [41]. Qualitative approaches also allow for more depth of insight and interpretation of meaning than is usually possible with the structured instruments of hypothetical-deductive research [42]. To increase our understanding of what innovation means in nature-based tourism in a region, and to determine factors behind innovation processes, we adopted case analysis as the qualitative method [41]. A case study approach opens up the possibility to make theoretical generalisations and contribute to theory building in the field [43], and which is a aim of this article. 
The focus in our case is on small firms involved in cooperation and networks, in order to explore whether these connections influence innovation in the firms. We chose one branch of nature-based tourism: firms offering sea-fishing and accommodation. One important reason for this choice was that a Norwegian tour operator, Din Tur, was established not only to operate as an ordinary tour operator but also to encourage and support the establishment of firms in the nature based sector of tourism. Nature based tourism firms in one specific region offering sea-fishing with accommodation, will experience much the same structural conditions regarding business activity, natural resources, population density, etc. By selecting the firms in one region, we thus had the possibility to exclude obvious differences related to nature and geography, and we could focus on the social, cultural, political and economic factors.

Studying innovation in nature based tourism in a specific region implies a study of several units, i.e. actors involved in innovation. We employed in-depth interviews of owner managers of twelve nature-based firms and informant interviews with two persons from the operator firm Din Tur. We also carried out additional informant interviews with actors in Innovation Norway, the main public financial institution for such firms. We analysed documents, website homepages, and newspapers as a background and basis for the interviews.

When selecting firms for interviewing, we wanted to study firms using Din Tur as a tour operator at present, but also some firms that had phased out their contract with this operator. The latter firms were chosen to search various experiences with this organisational model. We asked the tour operator to make a list of firms from the county of Troms meeting our specifications regarding to differences in age of the firms, size, localisation in the county, and diversification of services offered to tourists. We also wanted examples of firms who had withdrawn from contracts with the operator. Finally, we ended up with a list of 12 firms to visit, located in 6 different municipalities in the county, 2 of which had terminated their contract with Din Tur. An openstructured interview guide was developed for interviewing the owners of the firms. The interviews were carried out in June 2007 at the firms' headquarters. Each interview lasted from one to two hours and was recorded and transcribed. To facilitate analysis a summary was made across all the firms according to main issues.

\section{CONTEXT AND CASE}

In general there is a very high proportion of small firms in the Norwegian tourism industry, where more than $3 / 4$ of the companies had four or less employees in 2005 [8]. In nature based tourism, there is a predominance of small firms with low turn-over and low profit. The level of competence is low, and there is a scarcity of time and resources for competence development. Part of this problem is connected to seasonal variations, which make it difficult to offer full jobs all year round, and to keep a stable work force [8].

Our case study was carried out in the county of Troms, which is located in the northern part of Norway, i.e. 68-70 degrees north (Fig. 1). The number of inhabitants was 155800 in 2009 [44], with most of the population located in the two cities, Tromsø and Harstad. The countryside is sparsely settled and the main activities in these areas are still agriculture, but where the number of farmers is decreasing every year. Troms is known for its beautiful nature with high mountains dropping down into the sea.

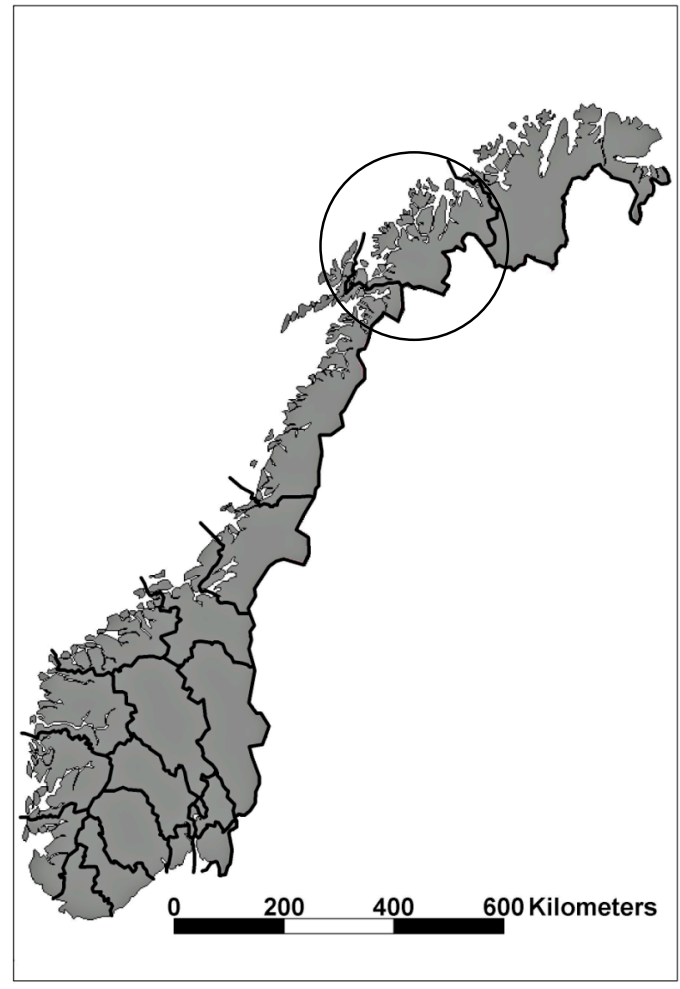

Fig. (1). The county of Troms in Norway.

Sea-fishing with accommodation was established as a tourism product in the late 1990s in northern parts of Norway, while tourism firms in the south had been offering this kind of product for many years. In 2008, there were between 40 and 50 firms offering mainly this product in the county of Troms, where 31 were suppliers to the tour operator Din Tur. In the two surrounding counties, Finnmark and Nordland, a significant number of such firms have also been established over the same period [45].

\section{Characteristics of the Firms}

In Table 1 in the Appendix, key characteristics of the 12 suppliers of sea-fishing are presented. The firms were very young; just two of the 12 firms had been established before 2000. Their capacity varied from 6 beds to 40 , where the average was $10-20$ beds. Turnover also varied. Eight firms had a turnover of less than 1 million NOK. There were great differences among the firms according to investments. Some rented out existing houses to augment their income from farming or other kinds of work. Like many family firms, these enterprises were based on a vision which places personal or family needs and preferences before growth and profit maximization [32]. Others had invested a substantial amount of money in, for example, building cabins, marinas, and well-equipped boats, and were obviously more focused on growth, profit and contributing to local development. Most owners worked in addition to their activities in tourism. None of the actors had any education or experience in 
tourism before they established their firm; which is in accordance with previous research results in the field [33].

Some firms offered a wider range of service products than others (appendix). This is partly related to the age of the firm, but also to professionalism. There were considerable variations in standard, size, equipment, facilities and additional products connected to the main product of sea-fishing with accommodation. Most of the firms were in the process of developing new products for winter and summer activities to expand the tourism season. Some firms had developed packages such as guided tours and activities made according to customer request. One firm had developed a more advanced range of packages for different customer groups and activities, lengths and time of year. On their homepages, most of the firms also marketed local adventure activities offered by other actors. However, according to the interviews, just a few customers asked for or used these offers. Their customers were mainly interested in fishing. All of the firms also marketed other free attractions such as walks in summer, cross country skiing and ice fishing in winter.

Almost all 12 firms wanted to increase their profitability. The main challenge was to expand the tourism season. This mainly meant offering other activities beyond the season for sea-fishing or, expanding the season for sea-fishing by, for example, offering winter fishing for "extreme tourism". The customers were mainly foreigners from different European countries, the greater share coming from Germany and Eastern Europe. Most firms lacked knowledge in their visitors' language, and this lack was pointed out to be one of their main challenges together with knowledge in marketing.

\section{The Tour Operator Din Tur}

For the ten firms using Din Tur as a tour operator, this actor constitutes an important part of the firms' network. Din Tur AS is organised as a limited company where the main shareholder is Allskog. Allskog is a cooperative owned by forest owners in the middle and northern Norway. The company Din Tur was established in 1996 because Allskog wanted to support their owners in developing nature based tourism. Din Tur has 13 employees and turnover in 2007 was 45 million NOK. The headquarters are located in Verdal, in the middle of Norway, but the company has also established an agency in Germany and a representative in UK to get closer to their customers. Din Tur offers activities like seafishing, fresh water fishing, kayak, hunting, bird watching, hiking, biking, canoeing, diving, off piste, winter sport, cross country skiing, dog sledding, snow shoeing, wildlife viewing, and horseback riding with accommodation. These activities are offered through their 215 suppliers of nature based tourism products located mainly in the middle and north of Norway [46].

The suppliers using Din Tur as a tour operator are offered an online booking system and a marketing operator. Din Tur is very active in following market trends in sea fishing, and their agency in Germany and representatives in the UK are important sources for this kind of information. The operator also gains knowledge through evaluations given from customers after their visits, which is important for improving the product. The company has also been very conscious of employing people with a lot of experience and a particular interest in sea fishing. Din Tur offer suppliers several other functions, like advising the firms in most areas, offering support in applying for finance, quality control, and lobbying activities if necessary. Recently, an important matter for Din Tur has been to encourage firms to diversify their offers in an attempt to increase the tourist season and find partners in their locality for offering supplemented activities to sea fishing. Once a year, Din Tur arranges a meeting for suppliers from each county to disseminate information and discuss different matters of common interest.

Another important activity, which separates Din Tur from other tour operators, is their efforts in encouraging and initiating the establishment of new firms in this sector. This work is done by visiting potential tourism actors directly and in arranging meetings for actors interested in starting tourism based on sea fishing. For interested actors, Din Tur has developed a kind of a manual/recipe for how to build a new tourism product based on sea- fishing. This recipe is very specific and detailed, and enables actors without competence in the field to build their new product. For many of the firms offering sea-fishing in Troms today, Din Tur has been an important driver and supporter for their establishment. The close cooperation Din Tur has established to the public support system for financing new businesses and their development, Innovation Norway, has obviously been an important factor in Din Tur's successful recruitment both according to new establishments and own suppliers. These multiple functions give Din Tur a central position in this specific tourism sector in Norway, as well as a special position in the firms, particularly those which they have helped to establish. Despite Din Tur differences from other tour operators in some areas, it is a professional tour operator which earns its money mainly from percentages of sales. The organisation also gets paid for its support to suppliers. In this way, establishing new firms in the sector is important for Din Tur, as is the firms' turnover and value adding. Because of the operators' "investment" in firms, they have now recently extended their contract with suppliers to last from one years to five.

\section{RESULTS}

First of all, we will analyse innovations in the 12 firms' studied, i.e. if it is possible to identify innovations among the firms and the characteristics of these innovations according to our first problem formulation.

\section{Product Innovations}

We now take a closer look at the product "sea-fishing". This product was newly developed in the county of Troms in the late 1990s, where firm C was among the first established. The operator Din Tur was also an important driver for the establishment of the industry in this county. The manager of Din Tur met a man from the Netherlands at a sea fishing fair in Rotterdam in the late 1990ies. This man was hired by Din Tur to support them in building up the sea-fishing concept in the county. This product was new in the region of Troms at that time and there was, no doubt, a need for a great deal of new thinking and creativity to develop and commercialise the product. Therefore, it is reasonable to define this product 
as a product innovation in this region in the late 1990s. Looking at the range of firms that have developed seafishing with accommodation afterwards, the products are very similar to those first established. Supported by Din Tur, which standardised the development of the product, little creativity was needed from the firm beyond adaptation to a new place. So the product of sea-fishing that has been established during recent years does not qualify for the definition of a product innovation. Rather, what we recognise in this case of sea-fishing is the diffusion of ideas about sea-fishing by the tour operator Din Tur, and thus adaptations of an innovation, i.e. an already developed product by the firms. This result is very much in line with earlier recognitions that tourism businesses mainly seem to be imitators and adaptors [3, 28]. However, when considering product development across all of the 12 firms, important development traits of innovation and diffusion are revealed.

We identified four different categories of product innovation related to the process of developing new products in these tourism firms. The first category of product innovation was the establishment of sea-fishing in the region; the second comprised changes in the range and combination of products offered; the third, further changes in the product content; and the fourth, the latest and more advanced product packaging.

\section{New Products Offered}

When sea-fishing with accommodation was first introduced in the county of Troms, it was an innovation in a regional perspective. Most products offered more recently by firms during our study, such as course and conference facilities, bicycle hire, guided mountain hikes and ski trips, were well known at the time of the case study, both in Troms and other places. These products do not therefore qualify as product innovations. There might be one exception: bird watching, which may have been a new product in the region at the time firm $\mathrm{C}$ established it in close cooperation with another adventure firm. From a regional perspective it is more correct to consider these new products as imitations and adaptations of existing innovations. Of course some of the offerings might hold innovative elements and thus be named creative imitations [13].

\section{Expansion of the Range and Combination of Products offered}

A step further in the process of developing sea-fishing tourism has been to extent the range of products on offer. We concluded above that neither sea-fishing with accommodation nor offering course and conference facilities qualify as innovative products. There are probably more actors than firms $\mathrm{C}$ and $\mathrm{E}$ that offer sea-fishing combined with course and conference facilities and accommodation. On the other hand, there are probably very few, if any, that can offer bird watching, hunting, bicycle hire, guided mountain hikes and ski trips, racing or riding reindeer, husky trips, ice-fishing, snowmobile trips, or watching the northern lights, as is done by firm $\mathrm{C}$. The development of this range of complementary products or product concepts offered from one tourism firm is, according to our definition, product innovation. This is in line with Van der Aa and Elfring [47], who argue that in many combinations "the components are not at all novel.
Rather, the new concept derives its novelty from the way the components are combined". The key to innovation is to find novel ways of linking service components, and thereby creating value for customers [13]. We can see that also many of the other firms studied strive to follow this strategy, to widen their range of products. The mediator Din Tur has been an important driver for its suppliers.

\section{Renewing the Product Content}

A range of products is offered for different needs and seasons by a few of the firms. It is not always easy to assess whether a single activity offered is innovative. It is necessary to know how the activity is organised in order to assess innovation and whether it represents a new offer or a major change. Firm E plans to hire a boat to take adventurers to attractive places for downhill skiing. They are to live on the boat and get their meals served there (ski-cruise). Earlier tourists in this small niche market were driven by car as close as possible to the mountain. When going by boat they usually get much closer to the peak which makes it possible to reach a higher number of peaks in a shorter time, and thus gives higher value for the target group. By our definition, this is a product innovation because it substantially changes the content and value of the original product for the target group.

Another example of change in product content is serving a meal. When a firm offers a meal made and served outdoors in connection with some activities, at a special place with a local history, or based on local food and food traditions, then it is possible to say that the product - the meal - represents a new adventure and a product innovation. Two of our case firms, $\mathrm{B}$ and $\mathrm{C}$, offer outdoor meals; firm $\mathrm{C}$ has developed their food concept much further than D.

Only a few firms have established the kind of new product content, but it seems to be an important step in the firms' innovative product development, which started just a few years ago among 2-3 of firms from our group. In these examples, we can see new product concepts more than we see new products. A range of products are intertwined in each offer, where our case firms offer only part of the products themselves. The offers require cooperation with other complementary tourism actors. These kinds of offers are more demanding than offering a range of products, both regarding competence, organisation, cooperation and general professionalism in order to succeed.

\section{Towards Product Packaging}

All firms in our study market a product package when offering sea-fishing and accommodation; some firms also offer additional products. The products offered vary greatly in how well they are packaged by the firms. Firm $C$, in particular, has developed well integrated packages for all seasons, such as multi-activity weeks, offers for short breaks, long or half weekends, and day programmes. It is possible to choose between a range of activities where the local coastal culture is a new ingredient. As far as we can see, this way of packaging products represents a new offer for customers. Whether it is a new product or an improved one - or both may be a question for discussion. The firms offer the same activities as previously, but they are now integrated as a complete offer which is supposed to give higher value for 
customers. Compared to changing content of a product, it is even more demanding to offer product packages, since these usually demand more cooperation and coordination with a lot of other actors. The direction of product development which we can dimly perceive among the more proactive firms in our case, show that innovation is not so related to a series of end products. Rather, it is more akin to a continuous process of shifting endeavours over time.

Few of the firms we studied have developed product, market, organizational or process innovations as defined. When innovation occurs, it is mainly in the form of improving and/or developing new products or product concepts. This continuous product development recognised in some of the firms is very much in line with Tether [26]. From the development of sea-fishing to product packages described above, incremental product innovations and product concept innovations are crucial for renewing and further developing the nature based tourism firms.

\section{Network and the Role of the Operator Din Tur}

Now we turn to our second problem formulation about firms' network and their role in the firms' innovation processes. Network activities varied among the firms. Some used more or less only Din Tur as a discussion partner and supporter in questions related to tourism, and were not part of other networks. In these firms, Din Tur handled their "necessary" network activities. These firms are marked with $\mathrm{S}$ (small) in the network column in appendix. Other firms have established, or are in the process of establishing, different networks both locally and regionally for tourism development. Most of these networks are include complementary producers of tourism products located quite close to the firm. Some firms have joined a local, newly established tourism organisation in their municipality, which they hope will be a positive contribution for their development. Innovation Norway is also mentioned as an important network by most of the firms because they have contributed with loans and other financial support. However, many of the firms complained about bureaucratic traits of this organisation and the time taken to process applications. Many firms also experienced difficulties with tourism development applications in their municipality, mainly because the land they wanted to use was defined for other purposes. What characterised the four firms with large networks (L) was that they had established a broader network both locally and regionally, they used many operators and offer a broader product range than the others. The two firms that withdrew from Din Tur are both in this group. However, two other firms with large networks considered the lack of networks in the county as a main constraint for their development. They pointed to the need for stronger networking among producers of tourism products, in order to discuss challenges and learn from each other.

For some firms, Din Tur had been crucial for their establishment and further development. These firms were mainly satisfied with the operator. When it comes to the other firms, their views were more differentiated. The main negative feedback relates to the tour operators' provision, i.e. its percentage share of sale, which seems to be high compared to other operators. Some firms find this acceptable because Din Tur offers more support than others. Others, and in particular the more developed firms, find the provision too high and argue that it should at least be differentiated according to the firms own effort in sales. Nearly half of the firms are dissatisfied with the number of customers ordered through Din Tur. Some firms also mentioned the risk when establishing new kind of products besides sea-fishing, because Din Tur has little competence and experience in those markets.

Only two suppliers of Din Tur used other operators in addition. One contacted other operators because Din Tur contributed too little to sales. The other firm established a lot of operators in winter tourism before he enlisted Din Tur as an operator for his newly developed sea fishing activity. The two firms withdrawn from Din Tur were mainly dissatisfied with the provision, but also lack of sales through the tour operator. One of the firms also mentioned that he and the operator occasionally had different views on marketing and product concepts to be developed for sea-fishing. These two actors cooperate with many other operators for the marketing and sale of their products, and seem to be amongst the more professional and expansive of the 12 firms studied. Firm $\mathrm{C}$ in particular had expanded more than others. This firm is very conscious about controlling its own development, has developed its own booking system and wants to follow up its own customers. In summary, the withdrawal from and dissatisfaction with Din Tur can partly be explained by an expansion beyond the sphere of an operator which has its knowledge and position on the more traditional sea-fishing market.

From this description of firms' networks, we recognise that channels for knowledge vary among the firms. While some mainly use Din Tur, which functions as a knowledge broker between the firm and the market, others have built more differentiated networks for gaining information and knowledge. Because of language problems reported by many firms, communication with customers is limited. Despite Din Tur give the firms some feedback on customers demand and wishes in general, an important source of ideas for product development and innovation is badly utilised by the firms [13].

Fig. (2) illustrates the network of firms offering seafishing where the operator is Din Tur. As described above, Din Tur represents the main network actor for many of these firms. The firms communicate regularly with the operator, and obtain information and knowledge from customers through the operator. Because of language problems it is mainly the operator that obtains feedback from customers. Therefore the arrows from the tourism firms to the operator and from the operator to the customers are bold and double, while the links from the firms to the customers are broken lines to show less communication and knowledge transfer. Also the firm's relation to other local firms seems to be rather superficial. They do not communicate regularly and do not cooperate much except that the sea-fishing firms market other local firms' offers on their home pages. Therefore this connection is not very well developed and seems to be mainly one-way. Other local firms marketed by the seafishing firms are typically not competitors but complementary. This means that they are directed to markets other than sea-fishing, which typically represents a niche market in tourism. When it comes to the support system, Innovation 


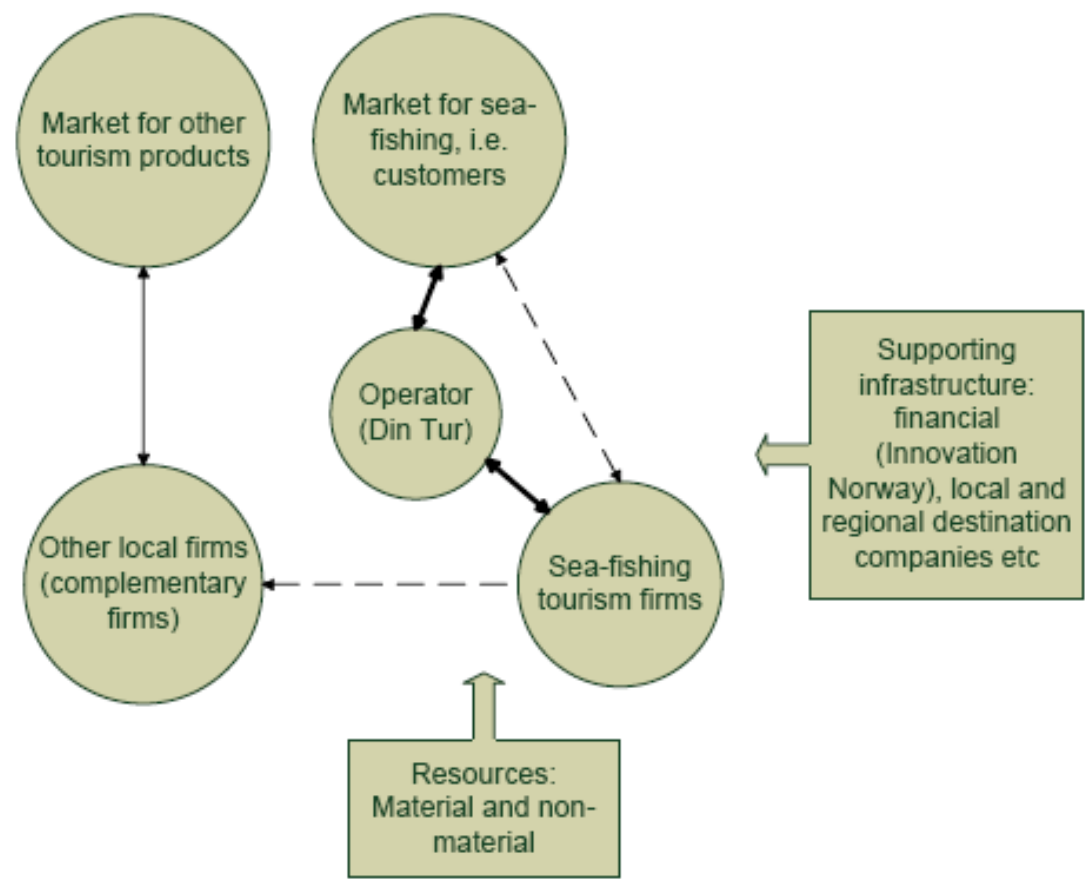

Fig. (2). Network related to supply of sea-fishing products where Din Tur is the tour operator.

Norway appears to be the main network for the firms contributing with financial support. Some firms belong to a local destination company as well, but this company is newly established and has not had any major effects yet. All in all, the networks for these firms using the operator Din Tur are very limited.

\section{DISCUSSION}

\section{Innovation and Imitation - Processes Involving Firms in Networks}

While we did not recognize much innovation among the firms studied, imitation occurred in many cases based on the diffusion of ideas and knowledge by the tour operator Din Tur. This case study shows that it might not be necessary that all tourism firms develop product innovations. In particular, when the market is sea fishing for which customers ask for the "same" product, innovation might not be necessary, at least not in the short run. If the tourism firms cooperate with other more innovative firms, like the operator Din Tur, this may compensate, at least in some fields, for the firms' need of innovative capacity.

To base its development on Din Tur is, however, a vulnerable strategy for tourism firms in the long run. It will be important to develop more differentiated knowledge channels for obtaining ideas, information and knowledge, and to be less dependent on the one actor. Today the firms' products are very similar; the only difference is simply their location. The firms that were developed based on Din Tur's standardised manual offer the more basic services at a relatively low standardised price - and they are all promoted in the same markets. There might therefore be possibilities to specialise, increase the quality of products, find new markets or broaden the existing market. The firms studied are mainly young and many of them are only just starting to build networks with other local tourism actors. In our case, it is only firm $\mathrm{C}$ that is in the early phase of developing something like a local cluster in its municipality, in which a lot of network links are established, as well as a business organisation to increase the local firms' value adding from tourism. In the long run this may also be a way of development for the other firms, enabling them to focus on distinct advantages in their local environment in cooperation with other local actors. In this way they may be able to develop a distinctive dimension in their product concept which differentiates them from others. This is a demanding strategy, but perhaps a necessary one to secure survival and, not least, local development.

To build networks and establish cooperation might be very demanding, in particular for small firms as studied here. In most cases, small firms need external support in these kinds of activities [48]. Support systems, apart from financial support from Innovation Norway, seem to be absent or lacking at both local and regional levels. There are some traces of cooperation at the local level among tourism firms in one municipality, beyond the one we have already mentioned, but this cooperation is at an early stage and little developed. On the whole, networks, which are seen as an important condition for innovation and development, are poorly developed among the firms studied.

\section{An Innovative Mediator's Push for Diffusion of Innovations}

As mentioned, Din Tur had 31 suppliers of sea fishing in the county of Troms in 2007. The diffusion process driven by Din Tur gives a foundation for developing a regional nature based tourism industry in the county. Together with other firms offering sea fishing in the county, they constitute a considerable economic activity. Even though the innovative elements, in the narrow sense of the definition, are limited in many firms, several of the firms have created, or are in the process of creating, new categories of products and 


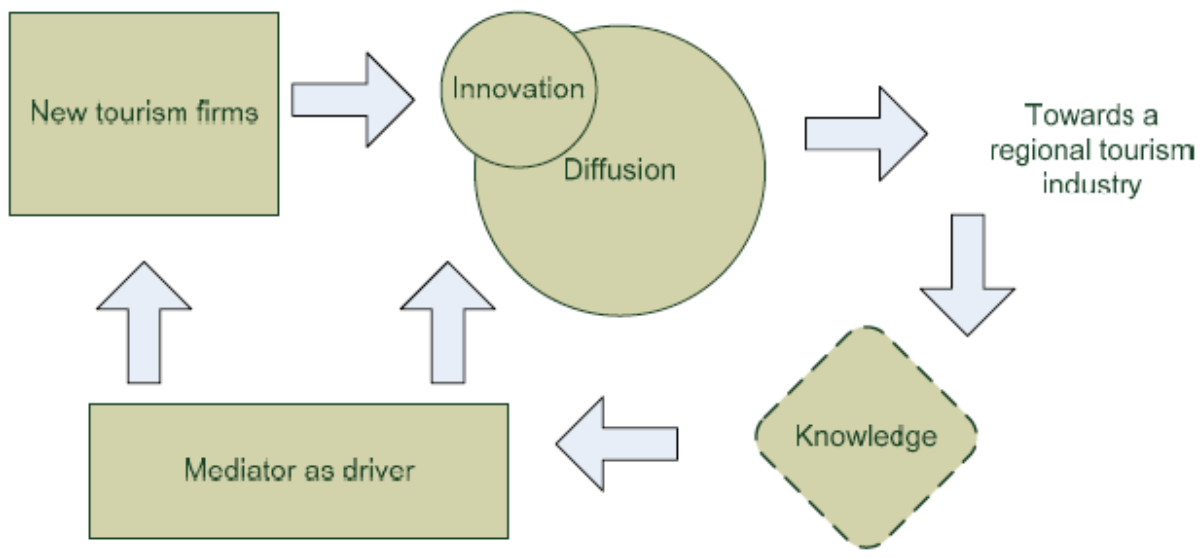

Fig. (3). Mediator as driver for diffusion of innovation.

thus new networks linked to these activities. Also, these activities are in many cases established because of encouragement from Din Tur. This operator has been a very important actor in the diffusion process of product innovations in the county but also an important driver for establishing local networks. With the range of all its functions, Din Tur has a mediator's role in the value chain of sea fishing tourism, but is also in itself an innovative organisation.

According to Fig. (3), the organisational model constitutes a dynamic system of diffusion of innovation. The mediator, Din Tur in this case, is the driver for diffusion. Through close contact with the market and its suppliers it gains information and knowledge, which is distributed as input into the firms as a basis for their further development.

After firms have been established and developed for some time, the ones with most recourses and ambitions have either withdrawn from Din Tur or become less satisfied with the tour operator. Thus, Din Tur seems to be a very important actor in recruiting and establishing firms, and an important market operator and distribution channel during the early years. Afterwards, it seem like other networks are more interesting for firms' development.

\section{Practical Implications}

For authorities and the support system, innovation is perceived as important and thus as important to support. But what about the diffusion and adaptation which are also needed to fulfil their goals of development? It is important to organise for both activities in parallel, but it is also important to understand the difference between them. According to our study, diffusion and imitation are crucial for disseminating innovations, which seem to be necessary to achieve value adding and rural development in the long run. This finding is in line with Keller [36] who claims that imitation is one of the most important means of disseminating innovations in the field of tourism. Scheidegger [5] also supports this, claiming that economic growth is dependent not only on the creation of new knowledge in the form of innovations, but on their dissemination and application. He further claims that such innovations only bring significant growth when they begin to spread. Diffusion and imitation are also challenging, but the novelty element of innovation makes it in most cases even more risky and thus more uncertain, demanding and time-consuming to develop and commercialise.
As Hjalager [3] suggests, it is important to support and increase competence in the support systems (mediators and drivers) for both innovation as well as the diffusion of innovations. According to our results, we suggest that financial support system and authorities at the municipality level should also adapt to the needs of small nature based firms, to contribute to positive development. At the same time, there is a considerable need for increasing competence and knowledge inside firms, which will make them more able to generate new knowledge both from inside and outside the firm and thus develop their innovative capacity. Firms lacked competence in many fields, such as sales, marketing, and economy. The need for competence in languages was a consistent concern. When we know that customers in many cases are the most important source of innovation [49], language is a very important area for increased competence among these firms.

The lack of local and regional networks and cooperation among the tourism firms is a main finding in our study. Because this kind of network seems important both for firms and their development, and also for local and regional development, authorities should focus more on the establishment of such, to better utilize the potential gains from tourism. Another important finding related to this is the lack of a regional innovation system, which is also often seen as an important condition for an innovative industry [40]. Two important cornerstones in a regional innovation system seem to be lacking: The support system toward nature-based tourism in the region seems to be poorly developed both at local and regional level, and the R \& D activity in the field of tourism seems to be nearly absent, at least in the firms studied. To increase competence among firms and potential gains from tourism a support system toward this kind of nature based firms is important to develop.

\section{CONCLUSION}

As an answer to our initial question about what kinds of innovations it was possible to identify, we found examples of product or product concept innovations. These innovations were characterized by being incremental and part of a continual process of improvements of the quality of the products offered. The innovativeness arose first of all in the offers of new combinations of products, new product contents and new product packages. The product development 
was among others based on a need for widening the tourism season beyond the season for sea-fishing, which in many cases implied a need for cooperation with other local tourism actors. To make profit, it is important to specialize to some degree and excel in one or a few products. The clue seems to be to find partners for cooperation in order to be able to offer a diversity of complementary products and establish attractive product packages that are less season-dependent.

The second question was about the role played by a tour operator and other actors in the firms' innovation processes. Our findings show that a mediator or tour operator works as a driver for diffusion of what can be an innovative product for tourists. The system of cooperation between the tour operator and the firms can unquestionably be characterised as an organisational innovation. The function of booking gives the mediator access to the suppliers with which it develops relations that in turn channel the diffusion of innovative tourism products. The main driving elements for the tour operator are searching for and establishing new suppliers, following standards of quality and stimulating additional product development on the part of the suppliers. This well established channel between the tour operator and the sea-fishing firms enables the diffusion of information and knowledge that may be hard to achieve for single firms on their own. However, the role of the mediator may not be sufficient for the expanding ambitions of some firms. We found examples of firms that had withdrawn from the mediators' contract and developed their own network.

Our study shows that even if product innovation is of crucial significance for establishing and renewing naturebased tourism, diffusion of product innovation is also of significance for expanding a nature-based tourism industry. In that way, both innovation and diffusion are relevant concepts in tourism development. In our analysis, the significance of innovation is found to be related to diffusion and to the system of stimulation of diffusion. Because the concepts of innovation and diffusion supplement each other, they should be used more frequently together in studies to show a more complete picture of tourism development in a region. Innovation may be a necessary but not sufficient factor for development, while innovation without diffusion may not develop a tourism industry.

\section{ACKNOWLEDGEMENTS}

This paper is part of a project at Centre for Rural Research, "Innovation in small-scale rural tourism: How to organise and co-operate for improvements and expansion?". The project is funded by the Norwegian Research Council, Forskningsmidler over jordbruksavtalen, and Sparebank 1 Midt-Norge. The authors want to thank the firms for interviews, Martin Rønningen for cooperation in the data

\section{APPENDIX}

Table 1. Characteristics of the 12 Sea-Fishing Tourism Firms

\begin{tabular}{|c|c|c|c|c|c|c|c|}
\hline Firm & $\begin{array}{c}\text { Establ. } \\
\text { year }\end{array}$ & $\begin{array}{c}\text { Contract with } \\
\text { operator Din Tur }\end{array}$ & $\begin{array}{l}\text { Turn-over } \\
\text { Mill NOK }\end{array}$ & $\begin{array}{l}\text { Beds } \\
\text { No. }\end{array}$ & Other products sold beside sea-fishing & $\begin{array}{l}\text { Network (Large, } \\
\text { Medium, Small) }\end{array}$ & $\begin{array}{c}\text { Owner(s) and } \\
\text { employment }\end{array}$ \\
\hline A & 1991 & $2003-$ & 0.5 & 20 & Bicycle hire & M & $\begin{array}{l}\text { Farmer and } \\
\text { machine operator, } \\
\text { part-time tourism }\end{array}$ \\
\hline B & 1995 & $2006-$ & 1.3 & 12 & $\begin{array}{l}\text { Guided mountain hikes and ski trips, husky trips, } \\
\text { snowmobile trips, watching northern lights, meals } \\
\text { based on outdoor cooking }\end{array}$ & $\mathrm{L}$ & Couple - retired \\
\hline $\mathrm{C}$ & 2000 & $2000-2006$ & $3-4$ & 36 & $\begin{array}{l}\text { Guided fishing trips, hunting, bicycle hire, guided moun- } \\
\text { tain hikes and ski trips, race or ride with reindeers, husky } \\
\text { trips, ice-fishing, snowmobile trips, watching northern } \\
\text { lights, facilities for courses and conferences, food, meals } \\
\text { based on outdoor cooking, different product packages }\end{array}$ & $\mathrm{L}$ & $\begin{array}{l}\text { Couple, husband } \\
\text { full time in tourism }\end{array}$ \\
\hline $\mathrm{D}$ & 2002 & $2003-$ & 0.4 & 16 & None & $\mathrm{S}$ & Couple - retired \\
\hline E & 2003 & 2004-2006 & 2 & 12 & $\begin{array}{l}\text { Camping, canoeing, glacier walks, mountain hikes and } \\
\text { climbing in summer. Winter activities include dog } \\
\text { sledging and snow scooter rides also for watching the } \\
\text { northern lights }\end{array}$ & $\mathrm{L}$ & $\begin{array}{l}3 \text { owners, also } \\
\text { employed } \\
\text { elsewhere, hired } \\
\text { general manager }\end{array}$ \\
\hline $\mathrm{F}$ & 2003 & $2003-$ & $?$ & 10 & None & $\mathrm{S}$ & $\begin{array}{l}\text { Farmers, part-time } \\
\text { tourism }\end{array}$ \\
\hline G & 2004 & $2004-$ & 1.7 & 40 & $\begin{array}{l}\text { Guided tours both in summer and winter, facilities for } \\
\text { courses and conferences }\end{array}$ & $\mathrm{L}$ & $\begin{array}{l}2 \text { couples, also } \\
\text { work elsewhere, } \\
\text { part-time tourism }\end{array}$ \\
\hline $\mathrm{H}$ & 2004 & $2004-$ & 0.2 & 8 & Mountain hikes, guided boat trips & $\mathrm{S}$ & Couple - work beside \\
\hline I & 2004 & $2004-$ & $?$ & 20 & None & $\mathrm{M}$ & Couple - soon retired \\
\hline $\mathrm{J}$ & 2005 & $2006-$ & 0.65 & 16 & None & M & $\begin{array}{l}\text { Couple, wife } \\
\text { fulltime in tourism }\end{array}$ \\
\hline $\mathrm{K}$ & 2006 & $2006-$ & 0.05 & 6 & None & M & Farmers \\
\hline $\mathrm{L}$ & 2006 & $2006-$ & 0.1 & 6 & None & $\mathrm{S}$ & $\begin{array}{l}\text { Couple, farmers, } \\
\text { part-time tourism }\end{array}$ \\
\hline
\end{tabular}


collection of the case study presented, Nancy Eik-Nes for valuable comments to draft of this paper and also for revising the language, Kiah Smith also for language revision, and two anonymous referees' and the editor Berit Brandt for giving us valuable comments on the article.

\section{REFERENCES}

[1] Bieger T. On the nature of the innovative organisation in tourism: Structure, process and results. Workshop on innovation and product development in tourism. Innsbruck, January 252005.

[2] Flagestad A. Destination as an innovation system for non winter tourism: Developent of a model. Workshop on innovation and product development in tourism, Innspruck, January 25, 2005.

[3] Hjalager AM. Repairing innovation defectiveness in tourism. Tourism Manage 2002; 23: 465-74.

[4] Keller P. Towards an innovation oriented tourism policy:A new agenda? Workshop on innovation and product development in tourism, Innspruck, January 25, 2005.

[5] Scheidegger E. Can the state promote innovation in tourism? Should it? Innovation and growth in tourism. OECD 2006.

[6] Briedenhann J. Wickens E. Tourism routes as a tool for the economic development of rural areas - vibrant hope or impossible dream? Tourism Manage 2004; 25: 71-9.

[7] Robers L, Hall P, Eds. Rural tourism and recreation: principles to practise. Oxon and New York: CABI Publishing 2001.

[8] Ministry of trade and industry. Verdifulle opplevelser. Nasjonal strategi for reiselivsnæringen. Regjeringens reiselivsstrategi: Nærings- og handelsdepartementet, Oslo: Norway 2007.

[9] Weiermair K. Product improvement or innovation: What is the key to success in tourism? OECD 2006.

[10] Miles I. Innovation in services. In: Fagerberg J, Mowery DC, Nelson RR, Eds. The Oxford Handbook of Innovation. Oxford: Oxford University Press 2005; pp. 433-58.

[11] Peters M, Pikkemaat B. Innovation in tourism. J Qual Assur Hosp Tourism 2005; 6(3/4): 1-6.

[12] Hjalager AM. The marriage between welfare services and tourismA driving force for innovation? In: Peters M, Pikkemaat B, Eds. Innovation in hospitality and tourism. The Haworth Press: USA 2005; pp. 7-29.

[13] Hall CM, Williams AM. Tourism and innovation. Routledge contemporary geographies of leisure, tourism and mobility. Taylor \& Francis Group: London and New York 2008

[14] Schumpeter J. The Theory of Economic Development. London: Transaction Books 1934.

[15] Schumpeter J. Theorie der wirtchaftlichen Entwicklung. Eine Untersuchung uber Unternehmergewinn, Kapital, kredit, Zins und Konjunkturzyklus. $9^{\text {th }}$ ed. Duncker and Humblot, Berlin 1997 in Hall CM, Williams AM. Tourism and innovation. Routledge contemporary geographies of leisure, tourism and mobility, Taylor \& Francis Group: London and New York 2008.

[16] Kanter RM. The change masters. London: Unwin 1983.

[17] Herskett JL. Managing in the service economy. Boston: Harvard Business School Press 1986.

[18] Johannessen JA, Olsen B, Lumpkin GT. Innovation as newness: what is new, how new, and new to whom? Eur J Innovat Manage 2001; 4/1:20-31.

[19] Teigen H. Innovativ forvaltning. Avgrensingar og omgrepsbruk. In: Rønning R, Teigen H, Eds. En Innovativ forvaltning? Bergen: Fagbokforlaget 2007.

[20] Fagerberg J. Innovation: A guide to the literature. In: Fagerberg J, Mowery DC, Nelson RR, Eds. The Oxford Handbook of Innovation, Oxford: Oxford University Press 2005.

[21] Nybakk E, Vennesland B, Hansen E, Lunnan A. Networking, innovation, and performance in Norwegian nature-based tourism. J Forest Prod Bus Res 2008; 5: Article No. 4.

[22] Rønningen M. Innovasjon i bygdeturisme. Rapport no. 05/09. Trondheim: Centre for Rural Research 2009; 29.
[23] Rogers EM, Ed. Diffusion of innovations. New York: Free Press 2003.

[24] Ottenbacher M, Shaw V, Lockwood A. An Investigation of the factors affecting innovation performance in chain and independent hotels. J Qual Assur Hosp Tourism 2005; 6(3/4): 113-28.

[25] Jensen CF, Mattsson J, Sundbo J. Succesfuld turistudvikling: Nøglen til innovation i turisme. Forskningsrapport 02:1, Centre of Service Studies, Roskilde 2002.

[26] Tether BS. Do Services Innovate (Differently)? Insights from the European Innobarometer SurveyInd Innov 2005; 12(2): 153-84.

[27] Sundbo J, Gallouj F. Innovation in services in seven European countries. Rep. Report 99:1, Center for servicestudier, Roskilde Universitetscenter, Roskilde 1999.

[28] Jensen CF, Mattsson J, Sundbo J. Innovationstendenser i dansk turisme. Rep. Forskningsrapport 01:1, Centre of Service Studies, Roskilde 2001.

[29] Tetzschner H, Herlau H. Turismeudvikling ved innovation og entrepreneurskab: Et potentiale for lokal erhvervsudvikling? Center for servicestudier, Roskilde 2002.

[30] Dosi G. The nature of the innovation process. In: Dosi G, Freeman G, Nelson C, Silverberg R, Soete L, Eds. Technical change and economic theory. London: Sage Publications 1988; pp. 221-38.

[31] Marengo L. Structure, competence and learning in an adaptive model of the firm. In: Dosi G, Franco M, Eds. Organization and strategy in the evolution of the enterprise. Macmillan Press: Houndsmill 1996; pp. 124-54.

[32] Getz D, Carlsen J. Family business in tourism - State of the art. Ann Tourism Res 2005; 32(1): 237-58.

[33] Hjalager AM. The immigrants on the tourism labour market. Paper for the IGU Study group of Sustainable Tourism, Flagstaff, Current Issuses in Tourism, October 1999.

[34] Valentine F. When companies learn, Innovation and the generation of knowledge in small andddd mediumsized danish enterprises. In: Borum F, Kristiansen PH, Eds. Technological innovations and organisational change. Danish patterns of knowledge, Network and culture. Nyt fra Samfundsviternskaberne, Institutt for Organisation og Arbejdssociologi, Handelshøjskolen i København 1989.

[35] Polanyi M. The Tacit Dimension. Garden City. N.Y: Doubleday Anchor 1967.

[36] Keller P. Innovation and tourism policy. In: Innovation and growth in tourism, OECD 2006.

[37] Fisher MM. Innovation, knowledge creation and systems of innovation. Ann Reg Sci 2001; 35: 199-216.

[38] Lundvall B̊̊, Ed. Pinter Publishers: National Systems of Innovation: Towards a Theory of Innovation and Interactive Learning. London 1992.

[39] Cooke P, Morgan K. The Associational Economy: Firms, regions, and innovation. Oxford: Oxford University Press 1998.

[40] Asheim BT, Isaksen A. Localisation, agglomeration and innovation: towards regional innovation systems in Norway? Eur Plann Stud 1997, 5: 299-330.

[41] Yin RK. Case study research: Design and methods. Thousand Oaks: Sage 1994.

[42] Ray D. Understanding the entrepreneur: entrepreneurial attributes, experience and skills. Entrepreneurship Reg Dev 1993; 5: 345-57.

[43] Eisenhard KM. Better stories and better concstructs: The case for rigor and comparative logic. Acad Manage Rev 1991; 16(3): 620-7.

[44] Statistics Norway 2009. Available from http://www.ssb.no

[45] Din Tur catalogue 2008. Din Tur, Verdal, Norway.

[46] DinTur.no 2010 (download 19.01.2010).

[47] Van der Aa W, Elfring J. Realizing innovation in services. Scand J Manage 2002; 18: 155-71.

[48] Kvam GT. Traditional Food as a Strategy in Regional Development: The need for knowledge diversity. In: Fonte M, Papadopoulos AG, Eds. Naming food after places: Food relocalisation and knowledge dynamics of rural development. Ashgate publishing Ltd, UK 2010 (Forthcoming).

[49] Von Hippel E. The sources of innovation. New York: Oxford University Press 1988 